ARCHIWA - Kancelarie - ZBIORY

NR 6(8)/2015

Sonia WaLESZCZuK

Uniwersytet Mikotaja Kopernika

\title{
Problem archiwizacji \\ Biuletynu Informacji Publicznej
}

http://dx.doi.org/10.12775/AKZ.2015.011

Słowa kluczowe

Biuletyn Informacji Publicznej; BIP; archiwizacja Internetu; wartościowanie zasobów Internetu; zasoby cyfrowe; administracja publiczna;

Keywords

Public Information Bulletin; PIB; archiving the Internet; Internet content evaluation; digital holdings; public administration

Streszczenie

W obecnych czasach bez wątpienia Internet odgrywa ogromną rolę w życiu codziennym. Staliśmy się społeczeństwem informacyjnym, które nieustannie poszukuje informacji. Coraz więcej spraw możemy załatwić za pomocą komputera, a życie prywatne w znacznym stopniu przeniosło się do świata wirtualnego. Artykuł jest próbą odpowiedzi na następujące pytania: jakie informacje są umieszczane na stronach BIP-u, jaka jest ich wartość dla prowadzonych badań, czy są to informacje niepowtarzalne, jakie informacje są umieszczanie na stronach internetowych podmiotów zobowiązanych do prowadzenia Biuletynu, jaki te informacje mają charakter oraz jaki jest stosunek zawartości stron internetowych tych podmiotów do zawartości ich BIP-u. 
(O) d kilkunastu lat Biuletyn Informacji Publicznej odgrywa znaczną rolę dla społeczeństwa. Za pośrednictwem BIP-u publikowane i gromadzone są najistotniejsze i najważniejsze dokumenty i informacje związane z działalnością podmiotów publicznych. Dzięki niemu każdy użytkownik w krótkim czasie może zapoznać się z działalnością i organizacją podmiotu, jego funkcjami, strukturą, kierownictwem i polityką kadrową.

Badając zagadnienie archiwizacji Biuletynu Informacji Publicznej, postawiłam następujące pytania: jakie informacje są umieszczane na stronach BIP-u, jaka jest ich wartość dla prowadzonych badań, czy są to informacje niepowtarzalne, jakie informacje są umieszczane na stronach internetowych podmiotów zobowiązanych do prowadzenia Biuletynu, jaki te informacje mają charakter oraz jaki jest stosunek stron internetowych do BIP-u.

Ustawa z dnia 6 września 2001 r. o dostępie do informacji publicznej ${ }^{1}$ nałożyła na instytucje wykonujące zadania publiczne obowiązek prowadzenia Biuletynu Informacji Publicznej. Ustawa w art. 6 dość szczegółowo określa, jakie rodzaje informacji publicznej podlegają udostępnianiu. Między innymi są to informacje o podmiotach, statusie lub formie prawnej, organach i osobach sprawujących funkcje i ich kompetencjach; zasadach funkcjonowania podmiotów, trybie działania, prowadzonych rejestrach, ewidencjach i archiwach oraz o sposobach i zasadach udostępniania danych w nich zawartych, a także o naborze kandydatów do zatrudnienia na wolne stanowiska.

Przeglądając losowo wybrane strony podmiotów Biuletynu Informacji Publicznej ${ }^{2}$, doszłam do wniosku, że na tych stronach w bardziej lub mniej rozbudowanej postaci umieszczane są wymagane informacje publiczne. Dużo zależy od podejścia i zaangażowania instytucji, a także od tego w jakim stopniu podmioty chcą się otworzyć na społeczeństwo. Duża liczba instytucji chętnie dzieli się informacjami co ciekawe, niektóre podmioty prowadzą rów-

${ }^{1}$ Ustawa z dnia 6 września 2001 r. o dostępie do informacji publicznej (Dz.U. 2001, Nr 112, poz. 1198 z późn. zm.).

2 Biuletyn Informacji Publicznej, https://www.bip.gov.pl/ [dostęp: 22 czerwca 2015], badaniu poddano następujące strony: http://www.bip.inwestpark.kadan.pl/, http://www. bip.pec-golubdobrzyn.ires.pl/, http://sp.krostoszowice.bip.info.pl/, http://www.bip.e-cea.pl/0311, http://bip.krynicamorska.tv/, http://bip.malopolska.pl/mtidtchalubinskiego/Article/get/id,186569.html, http://www.bip.umig.polaniec.pl/, http://bip.muzeum. torun.pl/, http://bip.mkidn.gov.pl/, http://bip.uni.torun.pl/ViewBIP?exec=dokument\&dok=524. 
nież „rejestr zmian dokumentu”, co niewątpliwie ułatwia analizę działalności i daje pełen obraz instytucji i zmian, jakie w niej zachodzą. Prowadzenie rejestru zmian dotyczy jednak tylko nielicznych podmiotów.

Instytucje, które nie prowadzą rejestru zmian, mogą zmieniać i usuwać informacje ze swojej strony BIP, co w konsekwencji prowadzi do utraty wcześniejszych danych i pozbawia użytkowników możliwości szybkiego dostępu do dawnych informacji. Możliwość wprowadzania zmian i usuwania wcześniej umieszczonych informacji na stronie Biuletynu jest niewątpliwie procesem nieodwracalnym. Z drugiej strony nie oznacza to, że informacje te zostały bezpowrotnie utracone. Biuletyn jest odzwierciedleniem istniejącej dokumentacji, która zostanie zarchiwizowana w instytucji. Mimo że jest to bardziej czasochłonne, osoba zainteresowana tymi informacjami zawsze może się zgłosić z prośbą o udostępnienie tych danych do konkretnej jednostki organizacyjnej.

Sam BIP ciągle się rozwija, dokonują się także przemiany w zakresie grafiki witryny, które mają na celu zachęcenie społeczeństwa do szybszego/łatwiejszego/przyjemniejszego zapoznania się z informacjami. Taką zmianę szaty graficznej mogliśmy w ostatnim czasie zaobserwować na stronie Biuletynu Naczelnej Dyrekcji Archiwów Państwowych³ ${ }^{3}$ która dzięki temu stała się przejrzysta i zachęcająca do zapoznania się z treścią. Za pomocą Wayback Machine, dostępnej na stronie największego projektu archiwizacji Internetu - archive.org, cofnęłam się do końca roku 2014 w celu porównania zawartości strony BIP NDAP z jej obecną odsłoną. W ciągu tych kilkunastu miesięcy treściowo strona nie uległa większej zmianie, została tylko uaktualniona o nowe informacje publiczne z bieżącej działalności. Następnie przeszłam do analizy innych zarchiwizowanych przez Wayback Machine stron BIP-u Naczelnej Dyrekcji Archiwów Państwowych. Wayback Machine pierwszą archiwizację strony NDAP już z zakładką BIP odnotowała w 2003 r. W celu zawężenia badań wybierałam jedną archiwizację z każdego roku, zazwyczaj były to ostatnie archiwizacje w danym roku. Do porównania zamieszczanych informacji publicznych wykorzystałam zakładkę „mapa serwisu”. W 2003 r. strona podmiotu nie była rozbudowana, zawierała podstawowe i najbardziej potrzebne informacje publiczne takie jak podstawy prawne działalności, w tym statut, regulamin, struktura oraz schemat organizacyjny, osoby spra-

${ }^{3}$ Biuletyn Informacji Publicznej Naczelnej Dyrekcji Archiwów Państwowych http:// bip.ap.gov.pl/dokument.php?iddok=1329\&idmp=2\&r=o [dostęp: 23 czerwca 2015]. 
wujące funkcje, adresy i telefony, godziny pracy, majątek i finanse oraz wniosek o udostępnienie informacji publicznej.

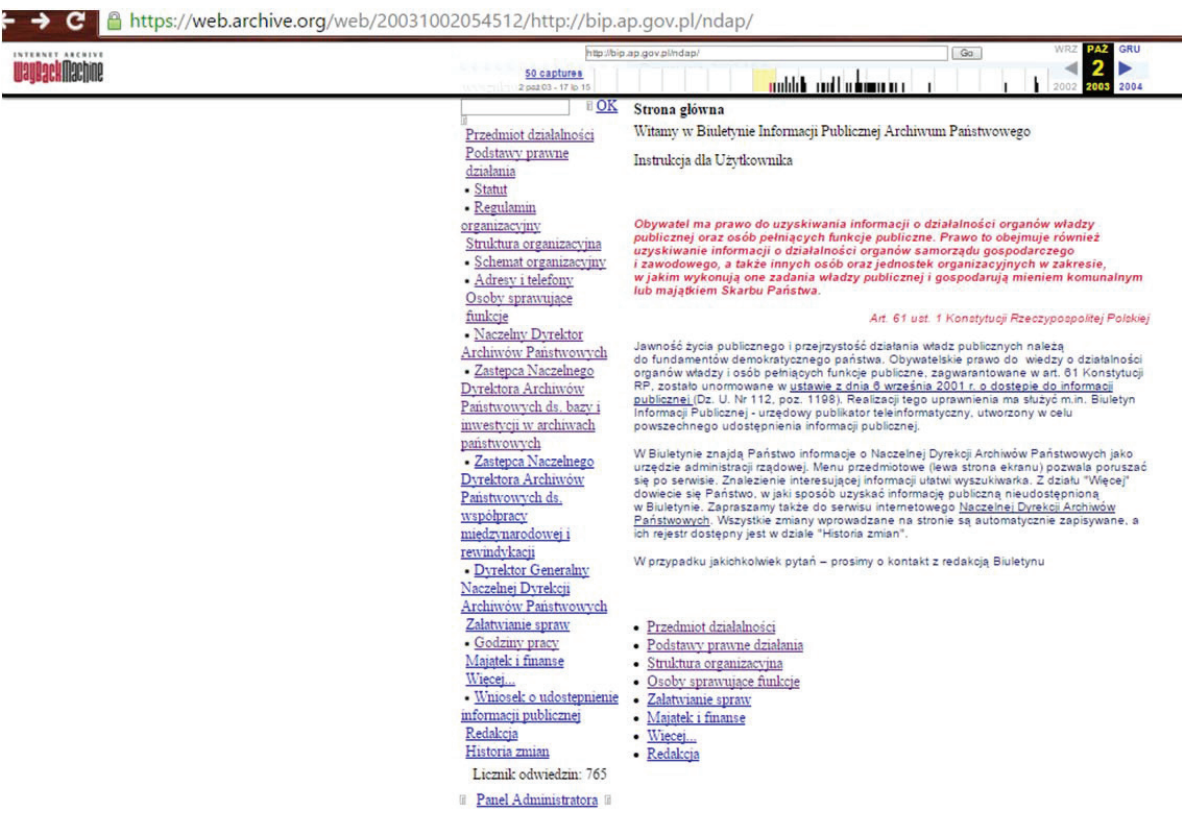

Rys. 1. Zrzut ekranu pierwszej zarchiwizowanej przez Wayback Machine strony BIP NDAP z 2003 r.

Źródło: https://archive.org.

W 2004 r. strona BIP NDAP została rozbudowana m.in. o takie elementy, jak: tryb załatwiania spraw, listy polecające, zaświadczenia na wywóz i czasowy wywóz archiwaliów za granicę czy też instrukcję dla użytkowników. W latach 2004-2009 strona Biuletynu Naczelnej Dyrekcji ulegała drobnym przemianom. Na przestrzeni tych lat dodawano informacje takie jak kompetencje Naczelnego Dyrektora Archiwów Państwowych, zakres obowiązków oraz informacje dotyczące udostępniania materiałów archiwalnych. W 2009 r. strona powiększyła się o elektroniczną skrzynkę podawczą, informacje o wolnych miejscach pracy oraz zostały rozbudowane informacje dotyczące zamówień publicznych. W roku 2010 wzbogacono stronę o rejestry, ewidencję, archiwa; skargi i wnioski oraz o kontrole i audyt. W kolejnych latach, 2011-2013, nie 
zaobserwowałam większych zmian. W roku 2014 BIP NDAP zaczął przyjmować swój obecny wygląd. Umieszczono w nim pełne i rozbudowane informacje.

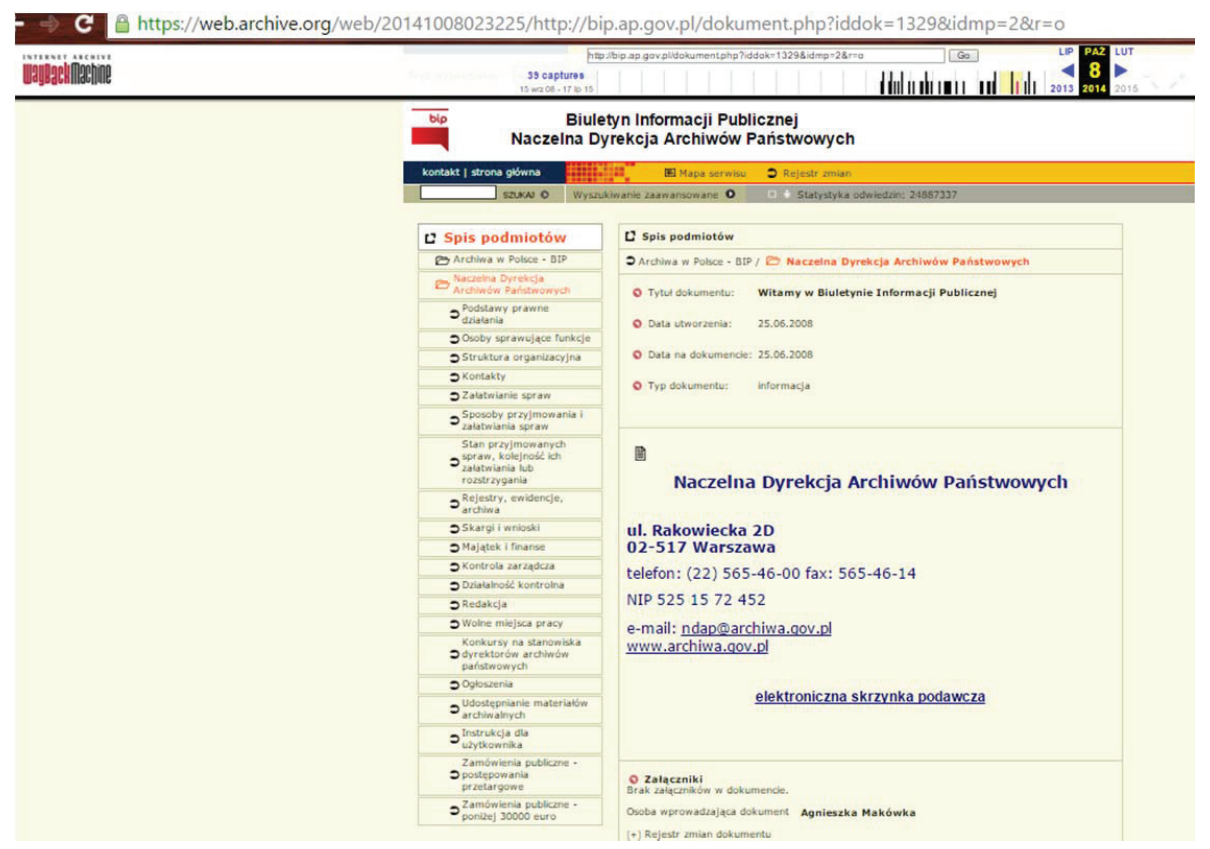

Rys. 2. Zrzut ekranu zarchiwizowanej przez Wayback Machine strony BIP NDAP przed zmianą szaty graficznej z $2014 \mathrm{r}$.

Źródło: https://archive.org.

W 2015 r., jak już wcześniej wspomniałam, strona BIP Naczelnej Dyrekcji uzyskała nową szatę graficzną. Przedstawiona przeze mnie analiza jest niczym innym jak drogą ewolucji, jaką przeszedł BIP NDAP. Możemy zaobserwować postęp i rozwój tej strony oraz zmieniające się podejście do jej prowadzenia przez podmiot. 


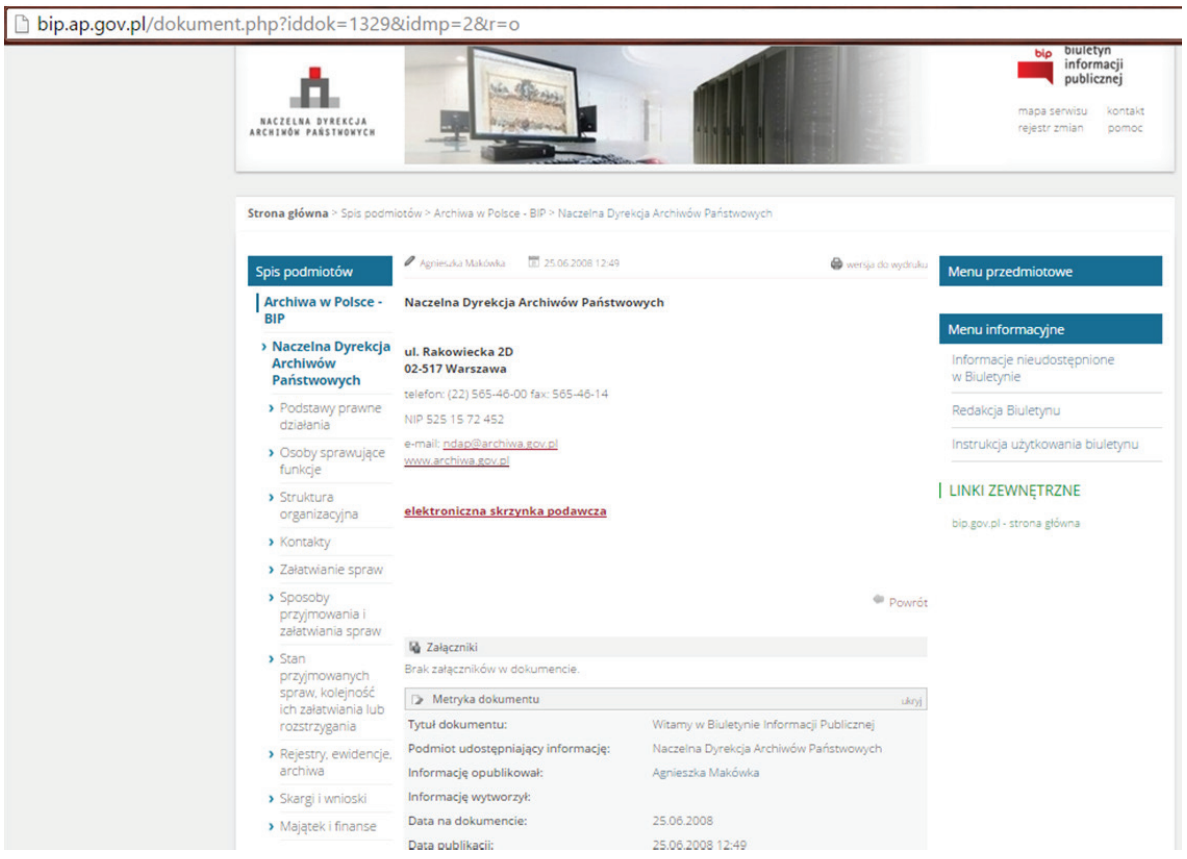

Rys. 3. Zrzut ekranu obecnej strony BIP NDAP z 2015 r.

Źródło: www.bip.ap.gov.pl.

Biuletyn Informacji Publicznej jako całość skupia w jednym miejscu informacje zamieszczane przez wszystkie władze i podmioty wykonujące zadania publiczne. Choć dane wpisywane i udostępniane są przez te różne podmioty, BIP gromadzi w jednym miejscu wszystkie najważniejsze informacje publiczne i umożliwia do nich szybki dostęp. Dla archiwistów może być cenną bazą informacji do badania i analizowania przedpola archiwalnego ${ }^{4}$. Jest przydatnym narzędziem, które umożliwia zapoznanie się z działalnością podmiotu oraz wstępne oszacowanie wartości tworzonych dokumentów. Mimo że w BIP-ie umieszcza się jedynie kopie oryginalnych dokumentów, to informacje w nim zawarte muszą być autentyczne, rzetelne i odzwierciedlające obecną rzeczywistość. BIP jest oficjalnym publikatorem państwowym wdrożonym

${ }^{4}$ H. Robótka, Nowa organizacja zarzadzania przedarchiwalnego, [w:] Archiwa nowe problemy, nowe rozwiąania: XVII Konferencja Archiwów Instytucji Kulturalnych i Naukowych Stowarzyszenia Archiwistów Polskich, Słupsk-Ustka, 7-9 czerwca 2009 r., red. A. Krzemińska, Słupsk-Kraków 2010, s. 9. 
na podstawie ustawy o dostępie do informacji publicznej, co czyni go jednym z ważniejszych źródeł informacji.

W Rozporządzeniu Ministra Spraw Wewnętrznych i Administracji z dnia 18 stycznia 2007 r. w sprawie Biuletynu Informacji Publicznej ${ }^{5}$ w rozdziale $3 \$ 9$ ust. 3 czytamy: „strona WWW podmiotu może być jednocześnie stroną podmiotową BIP, o ile spełnia wszystkie wymogi ustawy i rozporządzenia”. W swoich badaniach bardzo rzadko spotykałam się z takim rozwiązaniem, zazwyczaj podmioty na swoich stronach internetowych umieszczają logo i link umożliwiający bezpośredni dostęp do podmiotowej strony BIP. Na razie to rozwiązanie nie sprawdza się, ponieważ strony WWW nie spełniają zadań BIP-u oraz pełnią różne funkcje. Niektóre podmioty na swoich stronach internetowych umieszczają jednak jedynie szczątkowe informacje dotyczące organizacji działalności i funkcjonowania, całość tych informacji udostępniając poprzez Biuletyn.

Strony internetowe podmiotów są głównie nastawione na swój PR. Budowane są $\mathrm{w}$ taki sposób, aby nakłonić użytkownika do zapoznania się z instytucją i zachęcić go np. do skorzystania z usług jakie oferuje. Ich zadaniem jest zapoznanie użytkownika w łatwej i przyjemnej formie z tym, czym podmiot zajmuje się na co dzień. Instytucje coraz częściej i coraz więcej uwagi przywiązują do tego, aby strona WWW miała profesjonalną szatę graficzną i jak najświeższe informacje umieszczane w aktualnościach. Aktualności są zwykle na stronie głównej, umieszcza się tam krótkie informacje, na zapoznanie się z którymi nie potrzeba dużo czasu; dotyczą one w szczególności bieżących i przyszłych wydarzeń, które instytucja organizuje lub w których bierze udział. Kolejnym elementem, którego zadaniem jest pobudzenie wyobraźni użytkownika, są umieszczane na stronach WWW galerie zdjęć, które mają budować pozytywne wyobrażenie o podmiocie.

$\mathrm{Na}$ niektórych stronach dla przyciągnięcia większej uwagi użytkowników umieszcza się zakładki edukacyjne, w których można znaleźć różne ciekawostki, przydatne informacje, jak również gry i zabawy dla najmłodszych. Idealnym przykładem jest m.in. strona Narodowego Archiwum Cyfrowego, gdzie można znaleźć kącik dziecięcy z zestawem gier i zabaw dla dzieci' ${ }^{6}$.

5 Rozporządzenie Ministra Spraw Wewnętrznych i Administracji z dnia 18 stycznia 2007 r. w sprawie Biuletynu Informacji Publicznej (Dz.U. 2007, Nr 10, poz. 68).

${ }^{6}$ NAC dla dzieci, http://www.nac.gov.pl/wiedza-i-edukacja/nac-dla-dzieci/ [dostęp 23 czerwca 2015]. 
Podmioty umieszczają także obowiązkowo swoje dane teleadresowe oraz wybiórcze informacje dotyczące organizacji. Unika się umieszczania rozbudowanych informacji o działalności. Dodatkowo można znaleźć linki odsyłające do innych informacji lub instytucji. Ma to na celu zachęcenie użytkownika do pogłębienia wiedzy oraz - w przypadku, gdy użytkownik potrzebuje konkretnych informacji - skrócenie jego poszukiwań.

$\mathrm{Na}$ stronach internetowych podmiotów nie powinno się umieszczać zbyt wielu informacji o charakterze urzędowym. Dobrze, że strony te są nastawione głównie na PR, a zapoznawanie się z nimi jest coraz łatwiejsze i bardziej przyjemne. Osoby zainteresowane działalnością instytucji zawsze mogą znaleźć te informacje za pomocą umieszczanego na stronie WWW linku z logiem BIP, który przenosi użytkownika bezpośrednio do strony Biuletynu podmiotu.

W obecnych czasach bez wątpienia Internet odgrywa ogromną rolę w życiu codziennym. Staliśmy się społeczeństwem informacyjnym, które nieustannie poszukuje informacji. Coraz więcej spraw możemy załatwić za pomocą komputera, a życie prywatne w znacznym stopniu przeniosło się do świata wirtualnego. Biuletyn Informacji Publicznej jako całość stanowi zbiór informacji o wszystkich podmiotach zobowiązanych do prowadzenia Biuletynu. Dostęp do tych informacji dzięki temu stał się prosty i nie zajmuje wiele czasu. Internet jest efemeryczny i ulotny, dlatego zasoby BIP warto zachowywać, żeby móc w prosty i szybki sposób powrócić do umieszczonych w nim informacji, stanowiących w sieci oryginalną, niepowtarzalną całość informacyjną.

\section{Bibliografia}

Ustawa z dnia 6 września 2001 r. o dostępie do informacji publicznej, Dz.U. 2001, Nr 112, poz. 1198 z późn. zm.

Rozporządzenie Ministra Spraw Wewnętrznych i Administracji z dnia 18 stycznia 2007 r. w sprawie Biuletynu Informacji Publicznej, Dz.U. 2007, Nr 10, poz. 68.

Biuletyn Informacji Publicznej, https://www.bip.gov.pl/.

Biuletyn Informacji Publicznej Naczelnej Dyrekcji Archiwów Państwowych, http://bip. ap.gov.pl/dokument.php?iddok=1329\&idmp=2\&r=o.

Robótka H., Nowa organizacja zarzadzania przedarchiwalnego, [w:] Archiwa - nowe problemy, nowe rozwiązania: XVII Konferencja Archiwów Instytucji Kulturalnych i Naukowych Stowarzyszenia Archiwistów Polskich, Stupsk-Ustka, 7-9 czerwca 2009 r., red. A. Krzemińska, Słupsk-Kraków 2010. 


\section{Summary}

The problem of archiving the Public Information Bulletin

There is no doubt, that contemporary the Internet plays an enormous role in everyday life. We became the information society, which constantly seeks information. More and more errands can be run by using computer, and a big part of personal life has been moved to the virtual world. The article is an attempt to answer the following questions: what information is put on PIB's sites, what is their value for research, is this information unique, what information is put on websites of subjects obliged to run the Bulletin, what is the character of the information, and what is the relation between content of these subjects' websites and their PIB's content. 